\title{
Oscillation of second-order differential equations with a sublinear neutral term
}

\section{RAVi P. AgArWAL, MARTin BOHNER, TONGXING Li and CHENGHUi ZHANG}

\section{ABSTRACT.}

This paper is concerned with oscillation of a certain class of second-order differential equations with a sublinear neutral term. Two oscillation criteria and two illustrative examples are included. In particular, the results obtained improve those reported in the literature.

Acknowledgements. This research is supported by NNSF of P. R. China (Grant Nos. 61034007, 51277116, 51107069).

\section{REFERENCES}

[1] Agarwal, R. P., Bohner, M. and Li, W. T., Nonoscillation and Oscillation: Theory for Functional Differential Equations, volume 267 of Monographs and Textbooks in Pure and Applied Mathematics, Marcel Dekker Inc., New York, 2004

[2] Agarwal, R. P. and Grace, S. R., Oscillation theorems for certain neutral functional differential equations, Comput. Math. Appl., 38 (1999), 1-11

[3] Agarwal, R. P., Grace, S. R. and O'Regan, D., Oscillation Theory for Difference and Functional Differential Equations, Kluwer Academic Publishers, Dordrecht, 2000

[4] Agarwal, R. P., Grace, S. R. and O'Regan, D., Oscillation criteria for certain nth order differential equations with deviating arguments, J. Math. Anal. Appl., 262 (2001), 601-622

[5] Agarwal, R. P., Grace, S. R. and O'Regan, D., The oscillation of certain higher-order functional differential equations, Math. Comput. Modelling, 37 (2003), 705-728

[6] Agarwal, R. P., Shieh, S. L. and Yeh, C. C., Oscillation criteria for second-order retarded differential equations, Math. Comput. Modelling, 26 (1997), 1-11

[7] Baculíková, B., Properties of third-order nonlinear functional differential equations with mixed arguments, Abstr. Appl. Anal., 2011 (2011), 1-15

[8] Baculíková, B., Oscillation criteria for second order nonlinear differential equations, Arch. Math., 42 (2006), 141-149

[9] Baculíková, B. and Džurina, J., Oscillation theorems for second order neutral differential equations, Comput. Math. Appl., 61 (2011), 94-99

[10] Džurina, J., Oscillation theorems for neutral differential equations of higher order, Czech. Math. J., 54 (2004), 185-195

[11] Džurina, J. and Stavroulakis, I. P., Oscillation criteria for second order delay differential equations, Appl. Math. Comput., 140 (2003), 445-453

[12] Erbe, L., Kong, Q. K. and Zhang, B. G., Oscillation Theory for Functional Differential Equations, Marcel Dekker Inc., New York, 1995

[13] Grace, S. R., Bohner, M. and Liu, A., On Kneser solutions of third-order delay dynamic equations, Carpathian J. Math., 26 (2010), 184-192

[14] Grace, S. R. and Lalli, B. S., Oscillation of nonlinear second order neutral delay differential equations, Rad. Math., 3 (1987), 77-84

[15] Hale, J. K., Theory of Functional Differential Equations, Springer-Verlag, New York, 1977

Received: 03.01.2013 ; In revised form: 05.07. 2013; Accepted: 19.08.2013

2010 Mathematics Subject Classification. 34C10, 34K11.

Key words and phrases. Oscillatory behavior, neutral differential equation, second-order.

Corresponding author: Tongxing Li; litongx2007@163.com 
[16] Han, Z., Li, T., Sun, S. and Sun, Y., Remarks on the paper [Appl. Math. Comput., 207 (2009) 388-396], Appl. Math. Comput., 215 (2010), 3998-4007

[17] Hasanbulli, M. and Rogovchenko, Yu. V., Oscillation criteria for second order nonlinear neutral differential equations, Appl. Math. Comput., 215 (2010), 4392-4399

[18] Karpuz, B., Öcalan, Ö. and Öztürk, S., Comparison theorems on the oscillation and asymptotic behavior of higherorder neutral differential equations, Glasgow Math. J., 52 (2010), 107-114

[19] Ladde, G. S., Lakshmikantham, V. and Zhang, B. G., Oscillation Theory of Differential Equations with Deviating Arguments, Marcel Dekker Inc., New York, 1987

[20] Li, T., Agarwal, R. P. and Bohner, M., Some oscillation results for second-order neutral differential equations, J. Indian Math. Soc., 79 (2012), 97-106

[21] Li, T., Agarwal, R. P. and Bohner, M., Some oscillation results for second-order neutral dynamic equations, Hacet. J. Math. Stat., 41 (2012), 715-721

[22] Li, T., Han, Z., Zhang, C. and Li, H., Oscillation criteria for second-order superlinear neutral differential equations, Abstr. Appl. Anal., 2011 (2011), 1-17

[23] Li, T., Han, Z., Zhang, C. and Sun, S., On the oscillation of second-order Emden-Fowler neutral differential equations, J. Appl. Math. Computing, 37 (2011), 601-610

[24] Li, T., Han, Z., Zhao, P. and Sun, S., Oscillation of even-order neutral delay differential equations, Adv. Difference Equ., 2010 (2010), 1-9

[25] Li, T., Rogovchenko, Yu. V. and Tang, S., Oscillation of second-order nonlinear differential equations with damping, Math. Slovaca, (2012), (in press)

[26] Li, T., Rogovchenko, Yu. V. and Zhang, C., Oscillation of second-order neutral differential equations, Funkc. Ekvac., 56 (2013), 111-120

[27] Lin, X. and Tang, X., Oscillation of solutions of neutral differential equations with a superlinear neutral term, Appl. Math. Lett., 20 (2007), 1016-1022

[28] Zafer, A., Oscillation criteria for even order neutral differential equations, Appl. Math. Lett., 11 (1998), 21-25

[29] Zhang, C., Agarwal, R. P., Bohner, M. and Li, T., New results for oscillatory behavior of even-order half-linear delay differential equations, Appl. Math. Lett., 26 (2013), 179-183

[30] Zhang, C., Agarwal, R. P., Bohner, M. and Li, T., Oscillation of third-order nonlinear delay differential equations, Taiwanese J. Math., 17 (2013), 545-558

[31] Zhang, C., Li, T., Agarwal, R. P. and Bohner, M., Oscillation results for fourth-order nonlinear dynamic equations, Appl. Math. Lett., 25 (2012), 2058-2065

[32] Zhang, C., Li, T., Sun, B. and Thandapani, E., On the oscillation of higher-order half-linear delay differential equations, Appl. Math. Lett., 24 (2011), 1618-1621

\author{
Department of Mathematics \\ TEXAS A\&M UNIVERSITY-KINGSVILLE \\ 700 UNIVERSITY BLVD., KINGSVILLE, TX 78363-8202, USA \\ E-mail address: agarwal@tamuk.edu
}

DEPARTMENT OF MATHEMATiCS AND STATISTICS

MISSOURI S\&T

ROLLA, MO 65409-0020, USA

E-mail address: bohner@mst . edu

SHANDONG UNIVERSITY

SCHOOL OF CONTROL SCIENCE AND ENGINEERING

JINAN, SHANDONG 250061, P. R. CHINA

E-mail address: litong×2007@163.com

SHANDONG UNIVERSITY

SCHOOL OF CONTROL SCIENCE AND ENGINEERING

JiNAN, SHANDONG 250061, P. R. CHINA

E-mail address: zchuiesdu.edu.cn 